\title{
After the Covid-19 Pandemic: Rethinking the Relationship between Technology and Teacher Training
}

\author{
Maria Grazia Simone $e^{1, *}$ \\ ${ }^{1}$ Faculty of Psychology, eCampus On Line University, Via Isimbardi, 10, 22060 Novedrate \\ CO, Italy \\ *Corresponding author: Faculty of Psychology, eCampus On Line University, Via Isimbardi, \\ 10, 22060 Novedrate CO, Italy. E-mail: mariagrazia.simone@uniecampus.it
}

Received: March 31, 2021 Accepted: May 7, 2021 Published: June 22, 2021

doi:10.5296/ije.v13i2.18792 URL: https://doi.org/10.5296/ije.v13i2.18792

\begin{abstract}
The paper proposes a reflection on the new development trajectories of teacher training in light of the impact with the Covid-19 pandemic. The health emergency is producing, among other aspects, a rethinking of the relationship between those who teach and new technologies. The hypothesis to be demonstrated is that the current experience is configured as an important opportunity for professional growth for the teacher if this profession becomes increasingly open to the demands of the present time, ready to respond to emergencies that may arise in teaching practice, skilled in managing and mastering a conscious and mature relationship with technology.

The paper also presents the partial results of a research, carried out in three Italian universities, on the relationship between teachers in the training phase and technologies in this pandemic time.
\end{abstract}

Keywords: teacher training, pandemic, technology 


\section{Introduction}

The Covid-19 pandemic took the form of an absolutely unexpected event, which required the management of extraordinary problems, on several levels, also in terms of teaching practice.

In the emergency time, rather demanding and painful decisions had to be taken, such as the closure of schools for half of the world's student population (Unesco, 2020), and intervention strategies were suddenly developed to ensure the right to education and to maintain the continuity of teaching and learning processes.

As was foreseeable, in this new situation the highest costs, in terms of infrastructural, structural and cultural accessibility, were borne by students with socio-economic disadvantages who are increasingly at risk of educational poverty (Istat, 2020).

The teachers found themselves in the middle of a great transformation: they were forced to give up traditional teaching method to resort to online teaching, often without any kind of experience or preliminary training. This has led to significant changes in the approaches and practices in use, favoring choices and solutions often not previously considered.

It is our belief that the experience of the adverse event, whatever it is, can educate and transform professionals working in the field of teaching and learning, urging them to equip themselves with other tools and further skills to grow and evolve, that is to change and give life to new behaviors, to further adaptive responses, to possible paths of existential change and professional empowerment.

From the ongoing emergency experience, and from what has been said so far, our research questions arise: how is the pandemic urging us to rethink the relationship between new technologies and teaching training? Can we look at the emergency, among other aspects, as a digital training opportunity for the teacher, such as to have positive consequences in daily teaching practice and in the professional development process?

We believe that teaching training, in situations of didactic emergency, draws reasons of utility by reflecting and acting in the space traced by a "semantic triangle", whose vertices are represented by the concepts of experience, reflection and transformation (Limone \& Simone, 2020).

Emergency, novelty, change, the transition phases of individual and social history and... everything that cannot be predicted, analyzed from this perspective, for the teacher can become a valuable training ground for:

- Experiential Learning (Kolb, 1984), as an opportunity thanks to which one learns from lived experience and reflection, from conceptualization and active experimentation of reality, to prepare and keep ready future intervention plans, sufficiently tested (something that was dramatically lacking in the experience with Covid-19);

- Reflective Learning (Dewey, 1961; Schön, 1987), intended as an opportunity to build knowledge and skills starting from oneself and one's own experiences, to be able to read more carefully what happens and derive rules of occurrence, regulatory criteria, intervention 
strategies, etc.;

- Transformative Learning (Merizow, 2003), seen as a continuous process of readjustment and redefinition of one's own reference frames to develop effective change management skills.

This interpretation, among other aspects, allows us to look at the emergency beyond a "deficient perspective" (the one that focuses attention only on the lack of personal freedom, security, direct contact with others, etc.), to see it as a generative field of stimuli, actions and reflections and even conceptualizations from which to derive learning and therefore, in this sense, it can be an emancipating experience (Paparella, Limone \& Cinnella, 2020).

This is what happened to many teachers during the lockdown. If, according to very recent research, during that period there was a significant gap in the preparation and training of teachers regarding the methods of teaching mediated by digital technology (Whalen 2020). At the same time, not a few teachers, traditionally averse to technology, to ensure the continuity of the teaching / learning process and of the communicative and relational process with the students, they approached it.

It is not excluded that they found some areas of advantage in digital technology, previously not adequately considered. Just as, in the workplace, those who were wary of smartworking began to become familiar with it, and even to appreciate the benefits for themselves and for their organization.

In the case of teachers, an advantage is gained from the emergency situation if we think about the hypothesized connection between experience, reflection and transformation, to be ready in the face of a sudden event, to find useful solicitations for one's own teaching style and to change one's own schemes, effectiveness in dealing with unforeseen and unpredictable situations, in which uncertainty is great, as are the needs and expectations of students and stakeholders in that same circumstance.

In the case of students, they are also called to accept the educational challenge imposed by the Coronavirus to improve their problem-solving skills and to implement digital skills (Onyema, Eucheria, Obafemi, Sen, Atonye et al., 2020).

Experience can become a factor of development (Di Nubila \& Fedeli 2010), even when it is achieved through new routes and uphill paths.

The emergency urges us to tackle problems in a new way, to acquire further skills, new learning opportunities, useful for implementing and optimizing action schemes and the repertoire of practices.

The emergency, in the school environment, should not be seen as a remote and unlikely event. It is to be contemplated among the things that can concretely happen during a school and training course. The "toolbox" of the profession, therefore, cannot fail to contemplate methods, tools and techniques to be used in such cases and, possibly, to be permanently imported into one's professional action. 


\section{Review of the Literature}

The average teacher, generally not used to teaching in a different way than the traditional one, during the lockdown caused by the pandemic, had the great merit of having prevented the general collapse of the school system due to the sudden loss of physical contact with students. The management of particularly critical factors was also significant: poor digital skills, lack of sound school policies, problems with connection and accessibility to Internet, lack of infrastructure, lack of funding, etc. (Onyema, Eucheria, Obafemi, Sen, Atonye et al., 2020).

Faced with the need to quickly adapt to another teaching style, the teachers, albeit with great difficulty, proved to be really resilient. They found themselves no longer simply dispensers of knowledge but mentors and motivators of their students (Onyema \& Deborah, 2019). Teachers confirm themselves as the main mediators (Damiano, 2013) and facilitators of the teaching-learning process and, during the school emergency (ongoing), they worked to set up flexible and resourceful online teaching and learning sessions for enhance the protagonism of the students.

If, during the lockdown of last spring 2020, a certain commendable solicitude and professionalism of the teachers was found, who were able to overcome many personal difficulties (the increase in workload, the lack of face-to-face relationship with students, bad connectivity, etc.) in order to ensure school continuity, nevertheless, as Giovannella, Perisco $\&$ Passarelli (2020) argue, the didactic strategies adopted in this emergency turned out to be very far from the ideal solutions to increase inclusion.

Recent Italian researches (Perla, Felisatti, Grion, Agrati, Gallelli et. al., 2020) highlighted that even among university teachers there have been criticalities in the use of innovative technological tools and suggest the opportunity to implement training courses in the use of technologies in teaching, both as regards the technical and didactic aspects.

It should be emphasized, aligning with the reflections of Rivoltella (2010), that it is not "informational literacy" that must grow among teachers, but the "technological culture", the one that allows to rethink the methods of construction, representation and sharing of knowledge. In fact, to manage the media, operational skills are not enough but we need cultural and critical frames.

Falcinelli \& Limone (2014) also reiterate that the introduction of technology is not the tool to automatically achieve innovation. An authentic transformation is possible only by exercising "educational wisdom" combined with an organizational capacity that allows the complex management of teaching-learning processes mediated by technology.

The time has come to deeply characterize the teacher's entire training curriculum with high-quality preparation from a technological perspective. It is a question of offering concrete opportunities for professional development so that those who teach do not yet make the mistake of replicating face-to-face teaching strategies (linear and often repetitive) using digital tools which, on the other hand, offer opportunities for reticular, hypertextual learning, dynamic and socially built in dialogue and cooperation. 
Once a greater mastery of digital skills has been achieved, teachers inevitably generate the will to rethink, innovating, their teaching practices to be ready to teach effectively in the plurality of formats, settings, situations.

\section{Initial Teacher Training and Pandemic in Italy}

Here we want to show the results, still partial, of a research carried out by us in three Italian universities in the period October 2020-May 2021 that concerned the relationship between teachers in training and the relationship with technologies in the pandemic era.

A multiple choice questionnaire was administered to approximately 750 teachers in the initial training phase. They attend teaching academic qualification courses (Active Training Internship, TFA) for support activities for students with disabilities in every school level (kindergarten, primary school, lower secondary school, upper secondary school).

TFA is a theoretical-practical training period that is activated at the main Italian universities and which, once completed, allows the teacher to obtain the necessary qualification to participate in school competitions as a specialized teacher on support activities for students with disability.

The teachers involved in the survey attended these courses in three distinct Italian universities:

\section{University of Foggia (Foggia)}

2. Link Campus University (Rome)

\section{University of International Studies (Rome)}

The questionnaire, consisting of thirty multiple choice questions, was divided into the following sections:

1. motivation to teach and professional skills

2. relationship with disability and the idea of inclusion

3. relationship with technologies

4. Covid and distance learning

We are dealing with a sample of subjects with a prevalent age of 40-50 years, mostly female, whose last qualification is the high school diploma and whose current job position is a teacher with annual assignment.

Here we are interested in the answers given by the teachers to the last two sections of the questionnaire. $54 \%$ of the sample believe they have a good relationship with technologies and $68.2 \%$ consider them to have a positive impact on the teaching-learning process. Regarding the frequency of use of technologies, $44.9 \%$ of the sample uses them daily, $39.6 \%$ weekly and the remainder of the sample on a weekly and fortnightly basis. As regards the practices of 
using technologies, the interviewees make more use of them, in their way of teaching, to carry out research on the Internet, to prepare teaching materials, to offer presentations to students. The most used tool for this last purpose is the IWB (multimedia interactive whiteboard).

A critical point that emerged was the scarcity of IT equipment in schools.

When asked about teaching activities during the lockdown caused by the pandemic, the interviewees were not very enthusiastic about distance learning, complaining above all about relational difficulties with students.

In general, this is a sample of teachers who, in the initial training phase, "wants to grow" and feel they need to strengthen their skills in three main spheres: methodological, pedagogical and psychological, observational, relational and empathic.

\section{Implications for the Practice of Teacher Training}

Teachers should not only be oriented to a more assiduous and conscious use of technologies, but above all to the ability to mediate in the online learning environment, to use teaching strategies oriented towards autonomy, to be more open to discussion and debate.

What we are experiencing at school due to the pandemic, from our point of view, urges us to identify two operational paths to raise the quality of teacher training practices:

a) Their inclusion in professional learning and training communities;

b) The use of simulation in the professional training.

\subsection{The Teacher and the Professional Community}

The reworking, integration and transformation of professional knowledge is not a process that the teacher carries out in a solitary way. It is an action to be socialized with one's own school community, with other colleagues, in order to generate a "community of thought" (Michelin, 2019), a sense of belonging and sharing of good practices, action plans, intervention models, enhancing individual differences and the richness of mutual knowledge.

The teacher, today more than ever, needs to be part of a community of teachers, with whom to constantly interact, share operational strategies for solving problems, develop good practices to never feel alone in the face of the new challenges that the profession launches and also in the face of emergency situations. The sense of belonging to a professional community also arises from the need to be part of a group of people united by a shared interest or similar problems. The result is the opportunity to exchange information, socialize experiences, share approaches, reflect on practice, acquire stimuli for the development of their skills, producing innovation.

It has now been demonstrated the need to create training contexts where, alongside traditional training courses, there are other paths that stimulate reflection and the sharing of work experiences between teachers (Schuck, Aubusson, Kearney \& Burden, 2013; Mak \& Pun, 
2015).

Improving online teaching practices, building partnerships between schools and learning communities among teachers who are called to teach online (Carey, Sadera, Quije Cai \& Filipiak, 2020) are useful also to inhibit their self-perception of isolation, of being alone in solving problems.

In this direction, in Italy, a virtuous experience is represented by Indire (National Institute of Documentation, Innovation and Educational Research) which, during the spring 2020 lockdown, has exploited the experience of accompanying schools along the processes of change and innovation gained in the years, and has designed activities and services aimed at teachers, students and families, focused on the value of the "Network" as a mentoring system. The Network of solidarity between schools ("The school for the school") and the Network between Public Research Bodies ("Public research bodies for schools") have contributed to the realization of a systemic approach to training support and improvement performance in the use of teaching methodologies and new technologies in the implementation of distance teaching and learning. The resulting communities now have structured bases, for shared contents, tools and methodologies, which allow to continue in a long-term, systemic strategy to support the development and implementation of digital teaching (Mangione, Mughini, Sagri, Rosetti \& Zuccaro, 2020).

\subsection{Simulation in the Teachers Professional Training}

The Covid-19 emergency has shown that, for teachers, adapting to an online learning environment, often unknown to them, has been stressful and tiring (Kong, 2020). It was necessary, among other aspects, to re-build the student-teacher relationship online, manage digital tools to support the delivery of content and respond to the changing needs of students (Deblurer, Denton, McKay \& Sicily, 2020).

This situation highlighted two particular needs of teacher training, in all phases of their career: on the one hand, to develop strategies and criteria, to exercise skills and to implement useful skills in emergency situations; on the other hand, take advantage of adequate training programs that aim at promoting specific skills for teaching and learning online.

To meet both needs, a training methodology that is useful is the simulation.

As has been shown above (Simone, 2004; 2006), simulation (on line or face to face) is a place of exercise, experimentation and acquisition of skills useful for one's professional action.

Simulation can be used and understood as an "approximation": gradual approach to reality, in order to achieve a greater understanding and management of meaning and actions. It is a methodology that, applied in the didactic field, allows to learn through exercise, experimentation and active reproduction of problems and situations according to an experiential learning model that strictly follows the steps represented by experimentation, analysis, reconceptualization.

The simulations, in the professional training, make it possible to experiment with every 
practicable alternative, develop skills and abilities, show expected behaviors.

The subject interacting in a situation characterized by simulation observes (on the screen or in a structured training setting in presence) the evolution of a phenomenon and, consequently, the behavior that the system expects from him, asks himself questions, refines problem solving skills, reflects on the causes and effects of one's actions and, thus, develops intrinsic abilities to decide and act independently (Amory, Naicker, Vincent \& Adams, 1999).

The professional training, carried out through frontal lessons, may be insufficient in providing the teacher with the operational tools necessary to optimize their working practice. The theoretical knowledge thus learned tends to remain abstract because the teacher is unable to effectively connect theory to professional practice.

Periodic simulation experiences, in the professional training, become an opportunity for the teacher to perform preparatory exercises, to become aware of some problems, to gain confidence with certain tools and to develop strategies aimed at effectively managing a new situation.

In recent months, most of the teachers and students have measured themselves with distance learning for the first time. Some, on the other hand, in more virtuous situations, already knew what it was for having carried out, on a regular basis, a few days of simulation of online teaching and learning sessions per year, just to be ready to face the eventual closure of the educational establishments for reasons related to disasters, pandemics, etc. (Whalen 2020). Using the simulation has generated situations of considerable advantage.

The simulation, among other aspects, also represents a useful strategy to ascertain the responsiveness and that of programming and training planning of those who are called to work, involving everyone and raising awareness of the importance of systematizing the resources present in the group.

The simulated experience ends with the debriefing phase, from which reinforcement messages and improvement annotations are obtained. In this way, it is possible to transform the simulation into a source of learning, developing good practices, guidelines, regulatory documents, some criteria for managing subsequent emergencies.

\section{Implications for Teacher Education Research}

Only in recent times the professional development of the teacher become the object of pedagogical attention, of ministerial policies and of school governance. The current guidelines look at it as a long-term process, which includes regular opportunities and experiences planned in a systematic way in order to promote the growth of the teacher (Perla, 2016). Nevertheless, it must be acknowledged that, in the face of favorable and encouraging definitions of the profession, developed by the European Commission (2005) as "highly qualified", "fully placed in the context of lifelong learning," mobile in the European and international space "," based on partnership "and specific recommendations (European Commission, 2007), aimed at improving the quality of training in this sense, there are still 
some important gaps related to the analysis of the teacher's professional development needs, to the use of quality in-service training, the lack of evaluation of the outcomes of continuing education, the general, poor appreciation, in society, of this figure and also some gaps in the preparation of teachers, difficulties and lack of incentives in updating and training (Oecd, 2005; Talis, 2013; Oecd, 2014).

If, in the near future, we want to leave any emergency logic to aim for structural changes in the teaching training, from our point of view one of the keystones lies in the integration, in teaching practice and professional knowledge, of a digital pedagogy to be included on a permanent basis, and not occasionally, in teacher training programs at all stages of their careers.

The professional development of teachers is a complex and multidimensional construct, aimed at the expert rationalization of knowledge through training and educational relationship practices matured in situations over the course of professional and working life (Margiotta, 2010).

In the steps of the teacher's professional development, within the initiatives and procedures aimed at improving skills and professional performance, digital training is a need that can no longer be postponed.

It is now agreed that the lack of specific preparation in this sense, through the preparation of specific training courses (Limone \& Pace 2016), inhibits the planning of quality educational itineraries; this can only generate additional difficulties in teaching and learning in times of emergency and also in usual teaching practice.

The development of information and communication technology has brought a surprising and revolutionary challenge to the idea and practice of traditional education. Internet technology offers new opportunities to integrate face-to-face learning with online learning methods. In the future, there is a trend towards using blended learning scenarios, combining various forms of learning and integrating a variety of ways to access content using mobile technology.

It is now necessary that the technological results obtained become part of the teacher's professional action, between presence and distance, through the reconstruction of new identity meanings recognizable only in the light of an authentic, meaningful and strategic learning on the part of the student (Entwistle \& McCune, 2004).

The university, in this process, plays a fundamental role as a driving force for continuous training of quality teachers and to respond to the needs, not only emergency ones, of the present time.

University is asked to redesign the training courses that propose technologies not as simple teaching support tools, but as cultural mediators, capable of affecting the logic and practice of the university institution also with regard to higher education and research (Loiodice, 2011).

From the university institution training opportunities and experiences are hoped to make the teacher an effective protagonist of the complexity of scientific, methodological and technological innovation. Research, teaching and learning practices, student growth and 
social development will benefit.

\section{References}

Amory, A., Naicker, K., Vincent, J., \& Adams, C. (1999). The use of computer games as an educational tool: identification of appropriate game types and game elements. British Journal of Educational Technology, 30(4), 311-321. https://doi.org/10.1111/1467-8535.00121

Carey, L. B., Sadera, W. A., Quije, C., \& Filipiak, S. (2020). Creating a Community of Practice for Educators Forced to Transition to Remote Teaching. In Ferdig, R. E., Baumgartner, E., Hartshorne, R., Kaplan-Rakowski, R., \& Mouza, C. (Eds.), Teaching, Technology, and Teacher Education during the COVID-19 Pandemic: Stories from the Field. Association for the Advancement of Computing in Education (AACE). Retrieved 13 January, 2021 from https://www.learntechlib.org/p/216903/

Damiano, E. (a cura di) (2013). La mediazione didattica. Per una teoria dell'insegnamento. Milano: F. Angeli.

Deblurer, K., Denton, C., McKay, A., \& Sicilia, E. (2020). Supporting Michigan Educators through the Transition to Online Learning. In Ferdig, R. E., Baumgartner, E., Hartshorne, R., Kaplan-Rakowski, R., \& Mouza, C. (Eds.), Teaching, Technology, and Teacher Education during the COVID-19 Pandemic: Stories from the Field. Association for the Advancement of Computing in Education (AACE). Retrieved 13 January, 2021 from https://www.learntechlib.org/p/216903/

Dewey, J. (1910). How We Think. tr.it. 1961, Firenze: La Nuova Italia. https://doi.org/10.1037/10903-000

Di Nubila, R., \& Fedeli, M. (2010). L'esperienza: quando diventa fattore di sviluppo. Lecce: Pensa Multimedia.

Entwistle, N., \& McCune, V. (2004). The Conceptual Bases of Study Strategy Inventories. $\begin{array}{llll}\text { Educational Psychology } & \text { Review, } & \text { 325-34. }\end{array}$ https://doi.org/10.1007/s10648-004-0003-0

European Commission (2007). Improving the quality of teacher education, Brussels, Communication from the Commission to the European Parliament and the Council.

Falcinelli, F., \& Limone, P. (2014). La scuola digitale: a che punto siamo? In Rivoltella P. C. (a cura di), Smart future. Didattica, media digitali e inclusione, Milano: F. Angeli.

Giovannella, C., Passarelli, M., \& Persico, D. (2020). The Effects of the Covid-19 Pandemic on Italian Learning Ecosystems: the School Teachers' Perspective at the steady state. Interaction Design and Architecture(s) Journal, 45(2), 264-286.

Kolb, D. (1984). Experiential Learning: experience as the source of learning and development. Englewood Cliffs: Prentice Hall. 
Kong, Q. (2020). Practical exploration of home study guidance for students during the COVID-19 pandemic: A case study of Hangzhou Liuxia Elementary school in Zhejiang Province, China. Science Insights Education Frontiers, 5(2), 557-561. https://doi.org/10.15354/sief.20.rp026

ISTAT (National Institute of Statistics) (2020). ISTAT statistics on poverty. Report YEAR 2019. Rome: National Institute of Statistics. Retrieved 13 January, 2021 from https://www.istat.it/it/files/2020/06/REPORT_POVERTA_20 19.pdf

Limone, P., \& Pace, R. (2016). Teacher training and digital paths. Revolution in the school: a project for lifelong learning. International Journal of Digital Literacy and Digital Competence, 7(1), 1-18. https://doi.org/10.4018/IJDLDC.2016010101

Limone, P., \& Simone, M. G. (2020). Emergency, experience, reflection and transformation. Towards new development trajectories for teaching professionalism. Proceedings of the Asduni International Conference "Teaching, professional recognition and innovation at the University", in press.

Loiodice, I. (2011). Università, qualità didattica e lifelong learning. Scenari digitali per il mutamento. Roma: Carocci.

Mak, B., \& Pun, S. (2015). Cultivating a teacher community of practice for sustainable professional development: beyond planned efforts. Teachers and teaching: theory and practice, 21(1), 4-21. https://doi.org/10.1080/13540602.2014.928120

Mangione, G. R., Mughini, E., Sagri, M. T., Rosetti, L., \& Zuccaro, A. (2020). La rete come strategia di sistema nel supporto alla scuola italiana in epoca di pandemia: la buona pratica coordinata da INDIRE. Lifelong LifeWide Learning, 17(36), 58-75.

Margiotta, U. (2010). Abitare la professione docente. Lecce: Pensa.

Merizow, J. (2003). Apprendimento e trasformazione. Il significato dell'esperienza e il valore della riflessione nell'apprendimento degli adulti, tr. it. Milano: Cortina.

Michelin, M. C. (2019). Dimensioni dell'operare e del pensare oltre il digitale. Formazione\&Insegnamento, 17(1), 139-148.

OECD (Organization for Economic Co-operation and Development) (2014). TALIS 2013 results: An international perspective on teaching and learning. Paris: OECD.

OECD (Organization for Economic Co-operation and Development) (2005). Teachers matter: Attracting, developing and retaining effective teachers. Paris: OECD.

Onyema, E. M., Eucheria, N. C., Obafemi, F. A., Sen, S., Atonye, F. G., Sharma, A., \& Alsayed, A. O. (2020). Impact of Coronavirus Pandemic on Education. Journal of Education and Practice, 11(13), 108-121.

Onyema, E. M., \& Deborah, E. C. (2019). Potentials of Mobile Technologies in Enhancing the Effectiveness of Inquiry-based learning. International Journal of Education, 2(1), $1-25$. 
Paparella, N., Limone, P., \& Cinnella, G. (2020). Pandemia. Apprendere per prevenire. Bari: Progedit.

Perla, L. (2016). Il docente professionale. Nuove epistemologie didattiche di formazione. Perla L., Tempesta M., Università e scuola per lo sviluppo della professionalità docente. Lecce: Pensa MultiMedia.

Perla, L., Felisatti, E., Grion, V., Agrati, L. S., Gallelli, R., Serbati, A., Vinci, V., Amati, I., \& Bonelli, R. (2020). Beyond the Covid-19 era: from emergency to professional development prospects. Excellence and Innovation in Learning and Teaching, 5(2), 18-37.

Rivoltella, P. C. (2010). Tecnologie, qualità della didattica e formazione degli insegnanti. In Rivoltella, P. C., \& Ferrari, D. (a cura di), Scuola del futuro? Appunti di una ricerca intervento sull'innovazione tecnologica. Milano: EduCatt.

Schön, D. (1987, ed. it. 2006). Formare il professionista riflessivo. Per una nuova prospettiva della formazione e dell'apprendimento nelle professioni. Milano: Angeli.

Schuck, S., Aubusson, P., Kearney, M., \& Burden, K. (2013). Mobilising teacher education: A study of a professional learning community. Teacher Development, 17(1), 1-18. https://doi.org/10.1080/13664530.2012.752671

Simone, M. G. (2004). Simulazione al computer in ambito didattico. Potenzialità, criticità e scaffolding. In Colazzo S. (Eds.), Di pietra in pietra. Viaggio attraverso le pietrefitte salentine. Lecce (Italy): Amaltea.

Simone, M. G. (2006). Simulazione. Strutture categoriali. In Paparella, N. (Eds.), Ontologie, simulazione, competenze. Lecce (Italy): Amaltea.

TALIS (Teaching and Learning International Survey) (2013). Results. An International Perspective on Teaching and Learning, Oecd Publishing.

Whalen, J. (2020). Should Teachers be Trained in Emergency Remote Teaching? Lessons Learned from the Covid-19 Pandemic. Journal of Technology and Teacher Education, 28(2), 189-199.

Unesco (2020). 290 Million Students Stay Home due to Coronavirus. Retrieved 13 January, 2021 from https://learningenglish.voanews.com/a/unesco-290-million-students-stayhome-due-to-co ronavirus/5317148.html 


\section{Copyright Disclaimer}

Copyright for this article is retained by the author(s), with first publication rights granted to the journal.

This is an open-access article distributed under the terms and conditions of the Creative Commons Attribution license (http://creativecommons.org/licenses/by/3.0/). 